\title{
New bradykinin analogues acylated on the N-terminus: effect on rat uterus and blood pressure
}

\author{
Olga Labudda ${ }^{1}$, Tomasz Wierzba ${ }^{2}$, Dariusz Sobolewski ${ }^{1}$, Małgorzata Śleszyńska ${ }^{1}$, \\ Łukasz Gawiński², Marketa Plackova ${ }^{3}$, Jiřina Slaninováa ${ }^{3}$ and Adam Prahl ${ }^{1 \bowtie}$ \\ ${ }^{1}$ Faculty of Chemistry, University of Gdańsk, Gdansk, Poland; ${ }^{2}$ Department of Physiology, Medical University \\ of Gdańsk, Gdańsk, Poland; ${ }^{3}$ Group of Peptide Biochemistry, Institute of Organic Chemistry and Biochemistry, \\ Academy of Sciences of the Czech Republic, Prague, Czech Republic
}

Received: 31 October, 2006; revised: 07 December, 2006; accepted: 18 December, 2006 available on-line: 09 January, 2007

\begin{abstract}
Our previous studies suggested that acylation of the N-terminus of several known $B_{2}$ antagonists with various kinds of bulky acyl groups consistently improved their antagonistic potency in rat blood pressure assay. On the other hand, our earlier observations also seemed to suggest that the effects of acylation on the contractility of isolated rat uterus depended substantially on the chemical character of the acyl group, as we observed that this modification might either change the range of antagonism or even transform it into agonism. Bearing all this in mind, we decided to synthesize seven new analogues of bradykinin by $\mathrm{N}$-terminal acylation with various acyl groups of a moderately potent $B_{2}$ antagonist, previously synthesized by Stewart's group, D-Arg-Arg-ProHyp-Gly-Thr-Ser-D-Phe-Thi-Arg. The analogues were tested in vitro for their blood pressure-lowering and uterotonic activities. The modifications either preserved or increased the antagonistic potency in the rat blood pressure test. On the other hand, all seven substituents negatively influenced the interaction with the rat uterine receptors. Our results may be helpful for designing new $B_{2}$ agonists and antagonists.
\end{abstract}

Keywords: bradykinin, $\mathrm{B}_{2}$ antagonists, rat blood pressure assay, rat uterotonic test in vitro

\section{INTRODUCTION}

Bradykinin (BK, Arg-Pro-Pro-Gly-Phe-SerPro-Phe-Arg), a member of the kinin system, is a nanopeptide involved in various physiological and pathophysiological processes. BK is produced naturally through cleavage of two plasma proteins (a high-molecular-weight kininogen and a low-molecular weight kininogen) by trypsin-like enzymes known as kallikreins. There are two functional kallikreins, plasma kallikrein, which acts upon the high-molecular-weight kininogen to produce BK, and tissue kallikrein acting upon the other precursor to produce kallidin (Lys-BK) (Bhoola et al., 1992). Activities of $\mathrm{BK}$ are mediated by kinin receptors expressed in almost all cells in the majority of species. These receptors belong to the G-protein-coupled family and their activation stimulates smooth muscle cells (Regoli \& Barabe, 1980; Bhoola et al., 1992), sensory nerve endings (Chau et al., 1991; Dray \& Perkins, 1993), causes vasodilation and microvascular leakage (Regoli \& Barabe, 1980; Bhoola et al., 1992) and modulates the response of immunocompetent cells (Bhoola et al., 1992; Burch \& Kyle, 1992). $\mathrm{BK}$ is also best known as a mediator of inflammatory responses and initiator of peripheral pain signal (Stewart, 1993). After injection into the skin, BK produces all of the basic signs of inflammation (Marceau et al., 1983; Proud \& Kaplan, 1988). Due to its ability to lower blood pressure, BK has been implicated in

${ }^{\square}$ Faculty of Chemistry, University of Gdańsk, J. Sobieskiego 18, 80-952 Gdańsk, Poland; tel.: (48 58) 345 0428; fax: (48 58) 341 0357; e-mail: ap@chem.univ.gda.pl

Abbreviations: Aaa, 1-adamantaneacetic acid; Aca, 1-adamantanecarboxylic acid; ACE, angiotensin converting enzyme; BK, bradykinin; BKA, BK analogues; DMF, N,N-dimethylformamide; Fmoc, 9-fluorenylmethocycarbonyl; HR, heart rate; Hyp, L-hydroxyproline; MPA, mean arterial pressure; Pbf, 2,2,4,6,7-pentamethyldihydrobenzofuran-5-sulfonyl; TFA, trifluoroactetic acid; Thi, L-thienylalanine; TIS, tri-isopropylsilane. 
the pathogenesis of several shock syndromes, particularly the septic or endotoxic shock. Two types of receptors, designated $B_{1}$ and $B_{2}$ (Bhoola et al., 1992), mediate the biological activities of $\mathrm{BK}$. $\mathrm{B}_{2}$ receptors are very widely expressed in most tissues and require the entire $\mathrm{BK}$ sequence for recognition. $\mathrm{B}_{1}$ receptors recognize and bind des-Arg'-BK only and their expression is rapidly induced by inflammatory stimulation.

The synthesis of BK analogues for structureactivity studies started shortly after the announcement of the structure of this hormone in 1960. However, the first report on bradykinin analogues able to antagonize the effects of BK in standard kinin assays, such as rat uterus, guinea pig ileum or rat blood pressure, only came 25 years later, with the description of [D-Phe $\left.{ }^{7}\right] \mathrm{BK}$ and $\left[\mathrm{Thi}^{5,8}, \mathrm{D}-\mathrm{Phe}^{7}\right] \mathrm{BK}$ (Vavrek \& Stewart, 1985). Hundreds of analogues with single or multiple substitutions were later designed and synthesized in many laboratories. In the course of these studies the role of amino-acid residues in all positions of BK, as well as the influence of various combinations of substitutions on the pharmacological activity of the resulting compounds were carefully investigated (Stewart \& Vavrek, 1991). A major improvement in the potency of BK antagonists was achieved in 1991, when potent $B_{2}$ blockers, carrying conformationally constrained amino acid residues of their C-terminal ends, were synthesized (Hock et al., 1991; Stewart et al., 1996).

In our laboratory we discovered that acylation of the $\mathrm{N}$-terminus of the already known $\mathrm{B}_{2}$ antagonists with various bulky groups consistently improves their antagonistic potency in the rat blood pressure assay (Lammek et al., 1990). From our results it is also evident that even minor changes in the structure of acylated bradykinin analogues might be crucial for designing more potent $B_{2}$-blockers. A comparison of the $B_{2}$ antagonistic potency of the analogues obtained by acylation of known antagonists with 1-adamantaneacetic or 1-adamantanecarboxylic acids is a good example of this effect. We have reported that the latter peptide, differing from the former only in the lack of a methylene group in the $\mathrm{N}$-acyl residue, was three times as potent as the former in the rat blood pressure assay (Lammek et al., 1991). We also obtained very promising results for the peptides acylated on their N-terminus with a small aromatic compound, 4-tert-butylbenzoic acid. Its activity was thirteen times that of the Stewart's peptide (Lammek, 1994). Our previous data also suggested that not only the size of the acyl group attached to the N-terminus of the peptide, but also chemical features of the substituent were crucial for $\mathrm{B}_{2}$-antagonism (Prahl et al., 1997b; Trzeciak et al., 2000). Bearing all these findings in mind, we decided to continue our investigations into the influence of $\mathrm{N}$ - terminal acylation on pharmacological activity of $\mathrm{B}_{2}$ antagonists. We designed seven new peptides, I-VII, by acylation of the $\mathrm{B}_{2}$-antagonist reported by Schachter (Schachter et al., 1987), D-Arg-Arg-Pro-HypGly-Thi-Ser-D-Phe-Thi-Arg, with 4-hydroxy-3-metoxybenzoic $\left(X_{1}\right)$, 4-hydroxybenzoic $\left(X_{2}\right)$, 3-hydroxy4-methylbenzoic $\left(X_{3}\right)$, 3-(2-hydroxyphenyl)propionic $\left(X_{4}\right)$, 3-(4-hydroxyphenyl)propionic $\left(X_{5}\right)$, 1-hydroxy2-naphthoic $\left(X_{6}\right)$ and 2-nornbornaneacetic acids $\left(X_{7}\right)$. The structures of these acids are as follows:

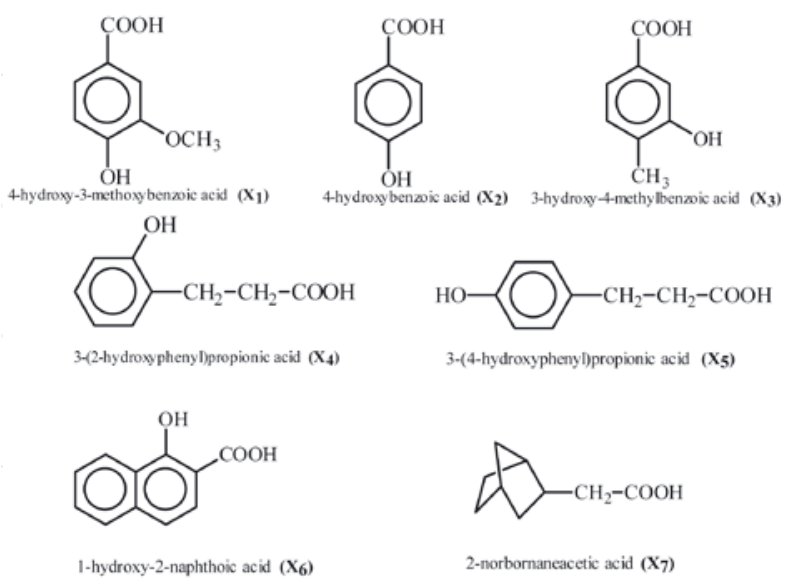

\section{EXPERIMENTAL PROCEDURES}

Experimental. Thin-layer chromatography (TLC) was carried out on silica plates (Merck). Spots were visualized with iodine or ninhydrin and the solvent system butan-1-ol/acetic acid/water/ethyl acetate (1:1:1:1, by vol.) [a] was used throughout.

Analytical high-performance liquid chromatography (HPLC) was carried out on a Waters Breeze System equipped with a Waters 1525 binary pump, Waters 2487 dual wavelengths absorbance detector and Waters 717plus autosampler. The purity of the peptides was determined on a Waters $\mathrm{C}_{18}$ column $(5 \mu \mathrm{m}, 100 \AA$; $150 \times 4.6 \mathrm{~mm})$. The following solvents were used: [A] $0.1 \%$ aqueous trifluoroacetic acid (TFA), [B] 80\% acetonitrile in aqueous $0.1 \%$ TFA $(\mathrm{v} / \mathrm{v})$. A linear gradient from 10 to $70 \%$ of [B] for $40 \mathrm{~min}$ was applied for peptides at a flow rate of $1 \mathrm{~mL} / \mathrm{min}$. Preparative HPLC was carried out on a Waters Millennium System equipped with Waters 600 pump with 600 controller and a Waters 2487 dual wavelengths absorbance detector using a Kromasil $\mathrm{C}_{8}$ column $(5 \mu \mathrm{m}, 100$ $\AA, 250 \times 25 \mathrm{~mm}$; in a gradient from 10 to $50 \%$ of [B] for $100 \mathrm{~min}$ at a flow rate of $10 \mathrm{~mL} / \mathrm{min}$, detection at $\lambda=226 \mathrm{~nm}$ ). The $\mathrm{FAB} / \mathrm{MS}$ of peptides were recorded on a TRIO-3 mass spectrometer at $7 \mathrm{keV}$ with argon as the bombarding gas and on a Bruker BIFLEX III MALDI TOF mass spectrometer (ionization: $337 \mathrm{~nm}$ nitrogen laser). 
Peptide synthesis. Peptides were synthesized by the solid-phase method on a Symphony/Multiplex $_{\text {TM }}$ Multiple Peptide Synthesizer (Protein Technologies Inc., USA) using the Fmoc-strategy and starting from Fmoc-Arg(Pbf)-Wang resin (Wang, 1973) (loading $0.33 \mathrm{mmol} / \mathrm{g}, 50 \mu \mathrm{mol}$ ). Fmoc protecting group was removed by $20 \%$ piperidine in DMF. A five-fold excess of respective Fmoc-amino acids was activated in situ using TBTU (1 equiv.)/ HOBt (1 equiv.) in DMF and coupling reactions were base catalyzed with DIEA (4 equivalents). The amino acid side chain protecting groups were tBu for Hyp and Pbf for Arg and D-Arg. All the Fmoc-protected amino-acids and the Fmoc-Arg( $\mathrm{Pbf})$ Wang resin were purchased from NovaBiochem (Bad Soden, Germany). 4-Hydroxy-3-metoxybenzoic $\left(\mathbf{X}_{1}\right)$, 4-hydroxybenzoic $\left(\mathbf{X}_{2}\right)$, 3-hydroxy-4-methylbenzoic $\left(\mathbf{X}_{3}\right)$, 3-(2-hydroxyphenyl)propionic $\left(\mathbf{X}_{4}\right)$, 3(4-hydroxyphenyl)propionic $\left(\mathbf{X}_{5}\right)$, 1-hydroxy-2-naphthoic $\left(\mathbf{X}_{6}\right)$ and 2-nornbornaneacetic acids $\left(\mathbf{X}_{7}\right)$, purchased from (Sigma, USA), were coupled in the final coupling step using the same procedure as that for Fmoc-amino acids.

Cleavage of the peptides from the resin with side-chain deprotection was performed by treatment with TFA/ $\mathrm{H}_{2} \mathrm{O} / \mathrm{TIS}$ (95:2.5:2.5 by vol.) mixture. The dried peptide-resin was placed in the reaction vessel, cooled in an ice bath and then $10 \mathrm{~mL}$ of the cooled cleavage mixture was added. Cleavage reaction was performed at room temperature (ice bath was removed after the cleavage mixture has been added) for $4 \mathrm{~h}$ under argon atmosphere. After the reaction was completed, the total volume of the TFA filtrate was reduced to about $1 \mathrm{~mL}$ and the peptides were precipitated with cold diethyl ether. The precipitate was filtered off, dissolved in water and lyophilized. The crude products were desalted on a Sephadex G-15 column, eluted with aqueous acetic acid (30\%) at a flow rate of $4.0 \mathrm{~mL} / \mathrm{h}$, detection at $\lambda=254 \mathrm{~nm}$. The eluates were fractionated and the fractions containing the major peak were pooled and lyophilized. All the peptides were purified by preparative HPLC. The physicochemical properties of the new analogues I-VII are presented in Table 1.

Effect of BK analogues on rat blood pressure. The antagonistic potency of the BK analogues was assessed by their ability to inhibit the vasodepressor response to exogenous BK in conscious rats. Male Wistar albino rats $(\mathrm{n}=58 ; 325-392 \mathrm{~g})$ were maintained on a regular chow diet and tap water at ambient temperature $\left(22 \pm 1^{\circ} \mathrm{C}\right)$.

Two days before the experiment, two arterial lines were led out under pentobarbital (pentobarbital sodium - 5-40-50 mg/kg i.p.) anesthesia for either injection of BK or infusion of the BK analogues. A Micro-Renathane ${ }^{\circledR}$ polyurethane based elastomer tubing (MRE-040, Braintree Scientific, USA) was inserted into the right carotid artery, while a RenaPulse ${ }^{\circledR}$ High Fidelity Pressure Tubing (RPT 040, Braintree Scientific, USA) with a tip made of MicroRenathane ${ }^{\circledR}$ MRE-040 tubing was indwelled into the right iliac artery. Both tubings, particularly recommended by American Heart Association for blood pressure measurement in experimental animals, have been reported to provide high fidelity of pulse waveform transmission with low susceptibility to intraluminal thrombosis. A Y-type connector was mounted to the tubing from the carotid artery. All catheters were exteriorized subcutaneously at the back of the neck. We allowed 40 to $44 \mathrm{~h}$ for recovery from the surgical catheterization to reduce the effect of neurohumoral activation related to trauma. In particular, we tried to minimize incoherent reactions related to an increase in endogenous catecholamines and BK, which might have interfered with our assay.

On the day of the experiment, the rats were placed in plastic cages. Mean arterial pressure (MAP) and heart rate (HR) were monitored through a Gould-Statham P23-ID pressure transducer (Gould, Cleveland, OH, USA) connected to the iliac catheter. The pressure signal was amplified, digitized at $1.5 \mathrm{kHz}$, visualized using dedicated software (UNIBIO, Kared, Poland) and saved on a computer hard disc. MAP and HR were assessed from the continuous sequence of the obtained blood pressure values using dedicated software (Analiza-2, Kared, Poland).

The ACE inhibitor enalapril (Merck Sharp and Dohme Research Lab., Rahway, NJ, USA; $1 \mathrm{mg} /$ $\mathrm{kg}$ ) was injected into the iliac catheter. Forty-five minutes were allowed for blood pressure stabilization. The rats displaying MAP equal to or lower than $85 \mathrm{~mm} \mathrm{Hg}$, or HR higher than 350 beats/min., were excluded from experiments $(n=5)$. Two doses of BK (bradykinin acetate salt; Sigma, USA, dissolved in a $5 \%$ D-glucose solution at a concentration of $1.25 \mu \mathrm{g} / \mathrm{mL}), 125$ or $250 \mathrm{ng}$ per animal, were randomly injected two to four times, every 4 to 5 min, into one branch of the carotid catheter, until the evoked vasodepressor responses were stable. To provide homogeneity of the assay, only the rats that exhibited vasodepressor response to $125 \mathrm{ng}$ BK ( $\triangle \mathrm{MAP}$ ) within the range of 20 to $45 \mathrm{~mm} \mathrm{Hg}$ were enrolled in this study. Furthermore, the rats which displayed the vasodepressor response to $125 \mathrm{ng}$ BK higher than $82 \%$ of that evoked by $250 \mathrm{ng}$ BK were also excluded from the BKA assay $(n=4)$. The BK dose of $250 \mathrm{ng}$ was then employed as a standard for the BKA activity assay.

The BK analogues dissolved in the $5 \%$ Dglucose solution were infused to the other branch of the carotid catheter. A constant rate of infusion (125 $\mu \mathrm{L} / \mathrm{min})$ was maintained using an infusion pump (F5z Dialyse 15; Dascon BV, Uden, Nether- 
Table 1. Physicochemical properties of BK analogues I-VII

\begin{tabular}{llllll}
\hline Analogue & Formula & HPLC $\mathrm{T}_{\mathrm{R}[\mathrm{I}]}$ & HPLC $\mathrm{T}_{\mathrm{R}[\mathrm{II}]}$ & Calculated & {$\left[\mathrm{M}+\mathrm{H}^{+}\right]$} \\
\hline $\mathrm{I}$ & $\mathrm{C}_{64} \mathrm{H}_{89} \mathrm{O}_{16} \mathrm{~N}_{19} \mathrm{~S}_{2}$ & 13.18 & 13.30 & 1444.67 & 1444.6 \\
$\mathrm{II}$ & $\mathrm{C}_{63} \mathrm{H}_{87} \mathrm{O}_{15} \mathrm{~N}_{19} \mathrm{~S}_{2}$ & 13.18 & 13.16 & 1414.64 & 1414.3 \\
$\mathrm{III}$ & $\mathrm{C}_{64} \mathrm{H}_{89} \mathrm{O}_{15} \mathrm{~N}_{19} \mathrm{~S}_{2}$ & 14.33 & 14.31 & 1428.67 & 1428.5 \\
$\mathrm{IV}$ & $\mathrm{C}_{65} \mathrm{H}_{91} \mathrm{O}_{15} \mathrm{~N}_{19} \mathrm{~S}_{2}$ & 14.28 & 14.28 & 1442.69 & 1442.3 \\
V & $\mathrm{C}_{65} \mathrm{H}_{91} \mathrm{O}_{15} \mathrm{~N}_{19} \mathrm{~S}_{2}$ & 13.66 & 13.66 & 1442.69 & 1442.6 \\
VI & $\mathrm{C}_{67} \mathrm{H}_{89} \mathrm{O}_{15} \mathrm{~N}_{19} \mathrm{~S}_{2}$ & 17.19 & 17.20 & 1464.70 & 1464.8 \\
VII & $\mathrm{C}_{65} \mathrm{H}_{95} \mathrm{O}_{14} \mathrm{~N}_{19} \mathrm{~S}_{2}$ & 15.12 & 15.75 & 1430.73 & 1430.3 \\
\hline
\end{tabular}

High-performance liquid chromatography (HPLC) was carried out on a Waters (analytical) chromatograph equipped with a UV detector $(\lambda$ $=226 \mathrm{~nm})$. The purity of the peptides was determined on a Waters $C_{18}$ column $(5 \mu \mathrm{m}, 100 \AA ; 150 \times 4.6 \mathrm{~mm})$. The following solvent systems were used: [A] 0.1\% aqueous trifluoroacetic acid (TFA), [B] acetonitrile : $0.1 \%$ aqueous TFA (80:20, v/v). A linear gradient from 20 to $80 \%$ of [B] for $30 \mathrm{~min}[\mathrm{I}]$ and a linear gradient from 20 to $60 \%$ of [B] for $20 \mathrm{~min}$ [II] were applied at a flow rate of $1 \mathrm{~mL} / \mathrm{min}$. The purity of all peptides determined on HPLC was between 96 and $99 \%$.

lands). The testing of the BK analogue potency was initiated with the 8-min infusion of the concentration of $1 \mu \mathrm{g} / \mathrm{mL}$ (this gave a dose of $125 \mathrm{ng} / \mathrm{min}$ ). During this infusion, a single $250 \mathrm{ng}$ dose of BK was injected twice: at $280 \mathrm{~s}$ and $450 \mathrm{~s}$ of the infusion. The concentration of the infused BK antagonist was then increased to 1.6, 6 or 12, and 32 or 64 (if necessary, up to 1024$) \mu \mathrm{g} / \mathrm{mL}$ to give the doses of 0.2 , 0.75 or $1.5,4$ or $8(128) \mu \mathrm{g} / \mathrm{min}$ per rat, respectively. As soon as the vasodepressor response to BK fell below $10 \%$ of the standard response, the procedure was completed. In the actual BK antagonist dose response pattern required, additional concentrations of BK antagonists were also employed: 3, 96, 256, and $360 \mu \mathrm{g} / \mathrm{mL}$ (doses $0.375,12,32,45 \mu \mathrm{g} / \mathrm{min}$ per rat, respectively).

The percent inhibition of the vasodepressor response to $250 \mathrm{ng}$ BK by the tested BK antagonists was plotted against the logarithm of the dose. From these dose-response curves, effective doses, $\mathrm{ED}_{20^{\prime}}$ $\mathrm{ED}_{50}$ and $\mathrm{ED}_{90}$, were determined representing doses of the BK antagonist $(\mu \mathrm{g} / \mathrm{mL})$ that inhibit vasodepressor response to the agonist (250 ng of BK) by 20, 50 and $90 \%$, respectively. The results are reported as mean values \pm S.D.

The in vitro rat uterotonic test. All the analogues were evaluated in the in vitro rat uterotonic assay using a modified Holton method (Holton, 1948) in Munsick solution (Munsick, 1960) on a strip of rat uterus. Wistar rats in estrus, induced by injection of estrogen $48 \mathrm{~h}$ before the experiments, were used. Bradykinin was used as a standard over the concentration range of $10 \mathrm{pM}$ to $10 \mathrm{nM}$. Cumulative dose response curves were constructed both in the absence and presence of various doses of the analogues, i.e. standard doses of BK were added suc-

Table 2. Pharmacological properties of new analogues of BK

\begin{tabular}{|c|c|c|c|c|}
\hline \multirow{2}{*}{ Peptide } & \multirow{2}{*}{$\begin{array}{l}\text { Uterotonic potency } \\
\mathrm{pA}_{2}\end{array}$} & \multicolumn{3}{|c|}{ Vasodepressor potency } \\
\hline & & $\mathrm{ED}_{20}(\mathrm{mg} / \mathrm{min})$ & $\mathrm{ED}_{50}(\mathrm{mg} / \mathrm{min})$ & $\mathrm{ED}_{90}(\mathrm{mg} / \mathrm{min})$ \\
\hline$\left[\mathrm{D}-\mathrm{Arg}^{0}{ }^{0} \mathrm{Hyp}^{3}, \mathrm{Thi}^{5}, \mathrm{D}-\mathrm{Phe}^{7}, \mathrm{Thi}^{8}\right] \mathrm{BK}$ & $6.88 \pm 0.08^{\mathrm{a}}$ & $1.73 \pm 0.43^{\mathrm{b}}$ & - & $124.17 \pm 27.04^{\mathrm{b}}$ \\
\hline Aaa[D-Arg ${ }^{0}, \mathrm{Hyp}^{3}$, Thi $\left.^{5},{ }^{5}-\mathrm{Phe}^{7}, \mathrm{Thi}^{8}\right] \mathrm{BK}$ & $7.43 \pm 0.11^{\mathrm{a}}$ & $0.84 \pm 0.09^{b}$ & - & $13.94 \pm 1.69^{\mathrm{b}}$ \\
\hline (I) $\mathrm{X}_{1}\left[\mathrm{D}-\mathrm{Arg}^{0}, \mathrm{Hyp}^{3}, \mathrm{Thi}^{5}, \mathrm{D}-\mathrm{Phe}^{7}, \mathrm{Thi}^{8}\right] \mathrm{BK}$ & $5.82 \pm 0.30$ & $0.18 \pm 0.02$ & $1.35 \pm 0.13$ & $20.17 \pm 2.39$ \\
\hline (II) $\mathrm{X}_{2}\left[\mathrm{D}-\mathrm{Arg}^{0}{ }^{0} \mathrm{Hyp}^{3}, \mathrm{Thi}^{5}, \mathrm{D}-\mathrm{Phe}^{7}, \mathrm{Thi}^{8}\right] \mathrm{BK}$ & $6.51 \pm 0.19$ & $0.46 \pm 0.08$ & $2.89 \pm 0.31$ & $36.36 \pm 6.33$ \\
\hline (III) $\mathrm{X}_{3}\left[\mathrm{D}-\mathrm{Arg}^{0}, \mathrm{Hyp}^{3}, \mathrm{Thi}^{5}, \mathrm{D}-\mathrm{Phe}^{7}, \mathrm{Thi}^{8}\right] \mathrm{BK}$ & $6.89 \pm 0.29$ & $2.04 \pm 0.37$ & $11.70 \pm 1.34$ & $122.62 \pm 24.28$ \\
\hline (IV) $\mathrm{X}_{4}\left[\mathrm{D}-\mathrm{Arg}^{0}, \mathrm{Hyp}^{3}, \mathrm{Thi}^{5}{ }^{5} \mathrm{D}-\mathrm{Phe}^{7}, \mathrm{Thi}^{8}\right] \mathrm{BK}$ & $6.38 \pm 0.25$ & $2.36 \pm 0.59$ & $10.97 \pm 1.72$ & $97.40 \pm 17.00$ \\
\hline (V) $\mathrm{X}_{5}\left[\mathrm{D}-\mathrm{Arg}^{0}{ }^{0} \mathrm{Hyp}^{3}, \mathrm{Thi}^{5},{ }^{5}-\mathrm{Phe}^{7}, \mathrm{Thi}^{8}\right] \mathrm{BK}$ & $6.26 \pm 0.10$ & $0.29 \pm 0.04$ & $1.38 \pm 0.11$ & $13.47 \pm 2.87$ \\
\hline (VI) $\mathrm{X}_{6}\left[\mathrm{D}-\mathrm{Arg}^{0}, \mathrm{Hyp}^{3}, \mathrm{Thi}^{5}, \mathrm{D}-\mathrm{Phe}^{7}, \mathrm{Thi}^{8}\right] \mathrm{BK}$ & $6.77 \pm 0.25$ & $0.39 \pm 0.07$ & $5.41 \pm 0.60$ & $222.55 \pm 54.81$ \\
\hline (VII) $\mathrm{X}_{7}\left[\mathrm{D}-\mathrm{Arg}^{0}{ }^{0} \mathrm{Hyp}^{3}{ }^{3} \mathrm{Thi}^{5}, \mathrm{D}-\mathrm{Phe}^{7}, \mathrm{Thi}^{8}\right] \mathrm{BK}$ & $6.40 \pm 0.14$ & $3.32 \pm 0.50$ & $18.94 \pm 1.92$ & $225.08 \pm 51.35$ \\
\hline
\end{tabular}

Agonistic activity calculated as percentage of BK activity (put at $100 \%$ ), antagonistic activity calculated as $\mathrm{pA}_{2}$ (negative decadic logarithm of analogue concentration shifting the log dose response curve for bradykinin by a factor of 0.3 to the right - calculations were made from the linear portions of the curves). $\mathrm{ED}_{20^{\prime}} \mathrm{ED}_{50}$ and $\mathrm{ED}_{90}$ represent doses of $\mathrm{BK}$ antagonist ( $\mu \mathrm{g} / \mathrm{kg}$ per min) that inhibit the va-

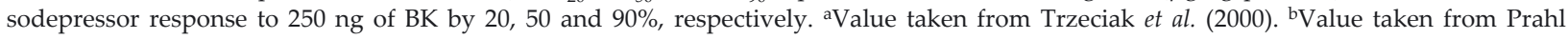
et al. (1997a). 
cessively to the organ bath in doubled concentrations and at $1 \mathrm{~min}$ intervals without the fluid being changed until the maximal contraction was obtained. The height of a single isometric contraction in response to different doses of bradykinin was measured. The antagonist was applied to the organ bath 1 min prior to the cumulative dosing of bradykinin. The antagonistic activity was expressed as $\mathrm{pA}_{2}$, i.e. the negative decadic logarithm of the analogue concentration which shifted the dose response curve of bradykinin by a factor of two (comparison of the linear portions of the dose-response curves). Each analogue was tested on uteri taken from 3-5 rats. As far as the agonistic activity of the analogues is concerned, it was calculated by comparing the threshold doses of cumulative dose response curves of the analogue and that of standard bradykinin. The activity of bradykinin was taken as $100 \%$.

\section{RESULTS AND DISCUSSION}

Seven new BK analogues (I-VII) were synthesized by stepwise coupling of Fmoc-amino acids to the growing peptide chain starting from a Fmoc$\operatorname{Arg}(\mathrm{Pbf})$-Wang resin. Cleavage of the analogues from the resin with side-chain deprotection was performed by treatment with a TFA/ $\mathrm{H}_{2} \mathrm{O} / \mathrm{TIS}$ solution. The crude products were purified on Sephadex G-15 and by RP-HPLC.

The antagonistic potencies of analogues I-VII, compared to those of the antagonist [D-Arg ${ }^{0}, \mathrm{Hyp}^{3}$, $\mathrm{Thi}^{5,8}$, D-Phe $\left.{ }^{7}\right]$ BK synthesized by Stewart's group, and its form acylated with 1-adamantaneacetic acid, obtained previously in our laboratory, are summarized in Table 2. The potencies of the analogues were assessed by their ability to inhibit the vasodepressor response of conscious rats to exogenous BK and by their ability to inhibit the contractions of isolated rat uterus evoked by BK. In the first assay, all the compounds exhibited moderate antagonistic potency. Analogues III and IV were approximately equipotent to the Stewart's peptide in inhibiting the effect of BK by $20 \%$ or $90 \%$. Analogues I, II, V and VI exhibited a very high activity in low dose of BK (ten, three, six and four times as high as the model peptide and four, two, three and two times as high as its acylated form, respectively). When inhibiting the effect of BK in higher doses, only analogue $\mathbf{V}$ was as active as the acylated model peptide, while analogues I and II showed a lower potency (two and three times, respectively), analogue VI was twice less active than the Stewart's peptide and twenty times less active than its acylated form. Analogue VII, which differs from the acylated model in its bulky acyl fragment only (adamantane rings were substituted by nornbornane rings) was much less ac- tive than its counterpart (four times in inhibiting BK activity by $20 \%$ and almost twenty times in inhibiting effects of BK by $90 \%$ ). In the rat uterus test, peptide I exhibited a very weak antagonistic activity, peptides III and VI were equipotent to the parent peptide, whereas peptides II, IV, V and VII showed a slightly lower potency than the parent peptide. All the new analogues were less active than the Stewart's peptide acylated with 1-adamantaneacetic acid.

It should be emphasized that all the analogues did not show any agonistic activity in either test.

In the present study we continue our previous investigations to find structural requirements which, in the case of BK analogues, result in high $\mathrm{B}_{2}$ antagonistic activity. As mentioned in the introduction, we reported previously that the presence of a bulky acyl group (1-adamantaneacetic acid, 4tert-butylbenzoic acid, 1-adamantanecarboxylic acid, etc.) at the N-terminus of $\mathrm{B}_{2}$ antagonists significantly influenced the interaction of the peptide with $B_{2}$ receptors thus increasing their potency (Lammek, 1994). Our results also suggested that even minor changes in the structure of the analogues might be important for $\mathrm{B}_{2}$ antagonism. On the other hand, we learned that the chemical character of the acyl group might differently influence the effects of acylations (Prahl et al., 1997b; Trzeciak et al., 2000). It seemed that either the positive or negative charge on the $\mathrm{N}$-terminal acyl group influenced the activity of the analogues, as we observed suppressed antagonistic potency due to these modifications.

In the present work we substituted seven new acyl groups in the $\mathrm{N}$-terminus of the model antagonist: 4-hydroxy-3-metoxybenzoate, 4-hydroxybenzoate, 3-hydroxy-4-methylbenzoate, 3-(2-hydroxyphenyl)propionate, 3-(4-hydroxyphenyl)propionate, 1-hydroxy-2-naphthoate and 2-nornbornaneacetate. The first six substituents are slightly acidic and all of them contain aromatic ring substituted differently with the hydroxyl group. The last-named (2-nornbornaneacetate) was chosen to learn how important the bulkiness of the acyl group is for $\mathrm{B}_{2}$ antagonism. As seen in Table 2, it is clear that the modifications preserved (analogues III and IV), increased (analogues I, II, V) or decreased (analogues VI, VII) the antagonistic potency in the rat blood pressure test. Moreover, the extent of the antagonism does not seem to depend on the acid strength, but rather on the substitution of the hydroxyl group in the aromatic ring and the distance of the bulky fragment of the acyl substituent from the main peptide chain. All the analogues acylated with 4-hydroxylated compounds are much more active than the Stewart's peptide and almost as active as its Aaa-acylated counterpart. It is also interesting to note that the distance of the substituted aromatic fragment of the acyl group from the main peptide chain influenced the antagonistic 
activity of the analogues. In the case of analogue II, in which the aromatic fragment is linked directly to the carboxyl group, its activity is a few times lower than that of analogue $\mathbf{V}$. In this case the aromatic fragment of the molecule is linked to the carboxyl group via two methylene units. The effect observed for this pair of analogues is reversed as compared to that previously observed for the peptides acylated on their $\mathrm{N}$-terminus with 1-adamantane acetic acid and 1-adamantine carboxylic acid (Lammek et al., 1991).

On the other hand, all the substituents differently influenced the interaction with the rat uterine receptors. In this case, five of our modifications resulted in less active $B_{2}$ blockers (I, II, IV, $\mathbf{V}$ and VII), while two of them (III and VI) preserved the antagonistic activity of the parent peptide. Moreover, it is very interesting that two of our most active $B_{2}$ antagonists in the blood pressure test are the weakest antagonists in the rat uterus test. This finding seems to suggests once more a different type of interactions with $B_{2}$ receptors localized in both types of tissues. Finally, looking at the activity of analogue VII, we have demonstrated how important the bulkiness of the acid used for acylation of the $\mathrm{N}$-terminus of the molecule is for the activity of BK antagonists. Thus, peptide VII, acylated with 2-norbornaneacetic acid, was a few times weaker antagonist than the model peptide and much less active than its acylated counterpart in both tests. It should be emphasized that the only difference between 1adamantane acetic acid and 2-norbornaneacteic acid used as acylating reagents is the size of the bulky polycyclic fragment.

In summary, our studies provided new information on the structure-activity relationship of bradykinin analogues that may have an impact on designing selectively acting bradykinin antagonists.

\section{Acknowledgements}

This work was supported by the State Committee for Scientific Research (Poland) grant No. PB 1108/T09/2005/28 and a research project of the Academy of Sciences of the Czech Republic Z40550506.

\section{REFERENCES}

Bhoola KD, Figueroa CD, Worthy K (1992) Bioregulation of kinins: kallikreins, kininogens and related kininases. Pharmacol Rev 44: 1-78.

Burch RM, Kyle DJ (1992) Minireview: Recent developments in the understanding of bradykinin receptors. Life Sci 50: 829-838.
Chau TT, Levin AC, Walter TL, Carlson RP, Weichmann BM (1991) Evidence for a role of bradykinin in experimental pain models. Agents Actions 34: 235-238.

Dray A, Perkins M (1993) Bradykinin and inflammatory pain. Trends Neurosci 16: 99-104.

Hock FJ, Wirth K, Albas U, Linz W, Gerhards HJ, Wiemer G, Henke St, Breipohl G, Konig W, Knolle J, Scholkens BA (1991) A new potent and long acting bradykinin antagonists. $\mathrm{Br}$ J Pharmacol 102: 769-773.

Holton P (1948) A modification of the method of Dale and Laidlaw for standardization of posterior pituitary extract. Br J Pharmacol 3: 328-334.

Lammek B (1994) Design and Synthesis of $B_{2}$-antagonists of bradykinin. Polish J Chem 68: 913-920.

Lammek B, Wang YX, Gavras J, Gavras H (1990) A new highly potent antagonist of bradykinin. Peptides 11: 1041-1043.

Lammek B, Wang YX, Gavras J, Gavras H (1991) A novel bradykinin antagonist with improved properties. $J$ Pharm Pharmacol 43: 887-888.

Marceau F, Lussier A, Regoli D, Giroud JP (1983) Pharmacology of kinins: their relevance to tissue injury and inflammation. Gen Pharmacol 14: 209-229.

Munsick RA (1960) Effect of magnesium ion on the response of the rat uterus to neurohypophysial hormones and analogues. Endocrinology 66: 451-457.

Prahl A, Wierzba T, Winklewski P, Musiał P, Juzwa W, Lammek B (1997a) Antagonists of bradykinin modified with conformationally restricted dipeptide fragment. Polish J Chem 71: 929-935.

Prahl A, Wierzba T, Wszędybył M, Juzwa W, Lammek B (1997b) Design and synthesis of new bradykinin antagonists with N-terminal acylation. Polish J Chem 71: 915-922.

Proud D, Kaplan AP (1988) Kinin formation: mechanisms and role in inflammatory disorders. Annu Rev Immunol 6: 49-84.

Regoli D, Barabe J (1980) Pharmacology of bradykinin and related kinins. Pharmacol Rev 32: 1-46.

Schachter LR, Uchida Y, Londridge DJ, Łabędź T, Whalley ET, Vavrek RJ, Stewart JM (1987) New synthetic antagonists of bradykinin. Br J Pharmacol 92: 851-855.

Stewart J (1993) The kinin system in inflammation. Agents Actions 42S: 145-149.

Stewart JM, Vavrek RJ (1991) The pharmacology of bradykinin receptors. In Bradykinin Antagonists. Basic and Clinical Research (Burch RM, ed) pp 51-96. Marcel Dekker Inc., New York-Basel-Hong Kong.

Stewart J, Gera L, Hanson W, Juzack J, Burkard M, Mc Cullough R, Whalley ET (1996) A new generation bradykinin antagonists. Immunopharmacology 33: 51-60.

Trzeciak HI, Kozik W, Melhem S, Kania A, Dobrowolski D, Prahl A, Derdowska I, Lammek B (2000) New bradykinin analogs in contraction of rat uterus. Peptides 21: 829-834.

Vavrek RJ, Stewart JM (1985) Competitive antagonists of bradykinin. Peptides 6: 161-166.

Wang SS (1973) p-Alkoxybenzyl alcohol resin and p-alkoxybenzyloxycarbonyl hydrazide resin for solid phase synthesis of protected peptide fragments. J Am Chem Soc 95: 1328. 